\title{
覀鉛湿式製鍊におけるケイ酸の挙動*
}

\author{
正会員鈴木信一郎**
}

\section{Studiss on the Behaviors of Silicic Acid during the Electrolytic Winning of Zinc}

Shin-ichiro SUZUKI

The behaviors of silicic acid during the electrolytic winning of zinc have been studied. Some effecis of silicic acid were made clear quantitatively.

1) During the roasting of zinc concentrate selective formation of lead silicate takes place.

2) Zinc silicate dissolves during the acidic leaching but not neutral leaching.

3) During the neutral leaching lead silicate decomposes and liberaies silicic acid into solution.

4) Below $\mathrm{pH} 2$ silicic acid remains as monomeric type but above $\mathrm{pH} 2$ polymerizes.

5) The concentration of silicic acid in zinc electrolyte is much higher than that estimated from solubility of amorphous silicic acid. By the precipitation of ferric hydroxide the concentration of silicic acid decreases remarkably.

6) Effect of silicic acid on the viscosity of electrolyte is very little.

7) No precipitation such as calcium silicate is observed.

\section{1. 緒言}

亜鉛電解採取に用いら机る亜鉛精鉱は必らずケイ酸を 含有する。乙かし電気亚鉛の製造工程である焙焼, 溶解, 清浄抢よび電解等の各過程に拄けるケイ酸の挙動に関し ては不明の点が多い。各工程産出物のケイ酸含有量注第 1 表》に示すようで, この表からもケイ酸の挙動の複雑 性がらかがわれる。よく知られているように, 浸出液に

第1表 亜鉛電解採取産出物中のケイ酸含有量 $(\%)$

\begin{tabular}{|c|c|c|}
\hline $\begin{array}{l}\text { 精鉱 } \\
\text { 溶解原料 } \\
\text { 㙛渣 }\end{array}$ & 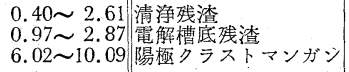 & $\begin{array}{l}1.49 \sim 2.19 \\
1.80 \sim 19.97 \\
0.15 \sim 1.20\end{array}$ \\
\hline
\end{tabular}

溶解したケイ酸は溶解工程の終点に近づくとコロイド状 ケイ酸として晶出し次の沪過工程の沪過速度を著しく減 少させるので有害な不純物である。しかし電解の際の添 加剤としてケイ酸ソーダを加え亜鉛の電着状態の改良に 役立てている製錬所 ${ }^{2}$ もある。

\section{2. 実験方法，結果および考察}

\section{$2 \cdot 1$ ケイ酸亜鉛の生成}

あめ色透明の閃亜鉛鉱およびケイ石をそれぞれ 250 mesh 以下に粉砕後閃覀鉊鉱に対して $20 \%$ のケイ石を混

* 昭和 38 年 7 月 31 日受理 昭和 38 年度春季講演会に発表

** 工博 秋田大学鉱山学部教授 治金学科
和した。

以上の混和試料を $750^{\circ} \mathrm{C} ょ り ~ 1,100^{\circ} \mathrm{C}$ まで $50^{\circ} \mathrm{C}$ 間隔で 空気を $50 \mathrm{~m} l / \mathrm{min}$ の流量で通しながら 1 時間磁製ボート 上で焙焼した。焼鉱のX線回折を第 1 図に示す。焙焼温

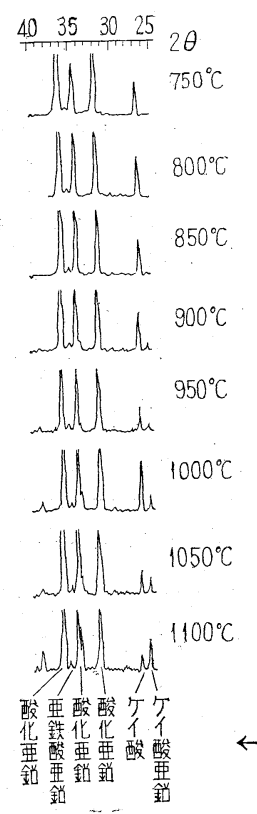

第 2 図焼鉱の $\mathrm{X}$ 線

回折

$\leftarrow$ 第 1 図焼鉱の $\mathrm{X}$ 線回折 
度 $850^{\circ} \mathrm{C}$ でわずかであるがケイ酸垔鉛 $2 \mathrm{ZnO} \cdot \mathrm{SiO}_{2}$ の生 成が認められる。

\section{$2 \cdot 2$ ケイ酸鉛の生成}

亜鉛精鉱に涌常 $1 \%$ 程度 ${ }^{1)}$ の鉛が含有されており, 鉛があると優先的にケイ酸鉛ができると報告されてい $b^{3)}$ 。

閃亜鉛鉣，方鉛鉱およびケイ石をそれぞれ $250 \mathrm{mesh}$ 下に粉研し，何れも純粋でそれぞれ $\mathrm{ZnS}, \mathrm{PbS}$ および $\mathrm{SiO}_{2}$ であると見なしてモル比 $1: 1: 1 の$ 割合に秤取し十 分混和してからさきの場合と同様に焙焼した。ただし焙 焼温度は $600^{\circ} \mathrm{C} よ り 800^{\circ} \mathrm{C}$ をとつた。 $800^{\circ} \mathrm{C}$ に焙焼した ものは完全に熔融してボートに固着しており， $750^{\circ} \mathrm{C} の$ 場合はところどころ熔融して大粒になつている。焼鉱の $\mathrm{X}$ 線回折の結果は第 2 図に示すようで, 焙焼湿度 $750^{\circ} \mathrm{C}$ で明らかにケイ酸鉛 $2 \mathrm{PbO} \cdot \mathrm{SiO}_{2}$ の生成が認められる。 以上の結果よりケイ酸鉛はケイ酸要鉛より $100^{\circ} \mathrm{C}$ 低い温 度で生成することが知られる。

\section{$2 \cdot 3$ ケイ酸重鉛およびケイ酸鉛生成に関する熱力学 的考察}

まず焙焼で硫化物が酸化物になり更にケイ酸と反忘し てケイ酸塩をつくると見なして，悪鉛および鉛のケイ酸 塩生成遊離エネルギー変化を求めた。

ケイ酸覀鉛の生成反応

$2\langle\mathrm{ZnO}\rangle+\left\langle\mathrm{SiO}_{2}\right\rangle=\left\langle\mathrm{Zn}_{2} \mathrm{SiO}_{4}\right\rangle$

の生成遊離エネルギー変化 $A G$ についてはJ.A. Kitchener および S. Ignatowicz ${ }^{4}$ の測定值がある。上式で く〉をつけたの注固体を表わす。

$$
\Delta G=-7,130+0.23 T \mathrm{cal}\left(300 \sim 1,300^{\circ} \mathrm{K}\right)
$$

$750^{\circ} \mathrm{C}$ の值を求めると一 $-6,895 \mathrm{cal}$ 在得る。またケイ酸 鉛については F.D. Richardson およびL.E. Webb ${ }^{5}$ が熔融ケイ酸鉛の生成遊離エネルギー変化から結晶ケイ 酸鉛のそれを計算で求め $743^{\circ} \mathrm{C} て ゙ ~-9,160 \mathrm{cal}$ を得てい る。ケイ酸塩の生成遊離エネルギー変化は温度勾配が非 常に小さいから焙焼温度による生成遊離エネルギー変化 は小さい。したがつて亜鉛精鉱の完全焙焼の温度範囲で 浢先的にケイ酸鉛が生成されると見なされる。

\section{$2 \cdot 4$ 焼鉱溶解におけるケイ酸亜鉛およびケイ酸鉛の} 挙動

a ）ケイ酸业鉛，実験に使用したケイ酸覀鉛は次のよ うにしてつくつた。すなわち化学用最純酸化亜鉛とケイ 石粉末をそれぞれ $160 \mathrm{~g}$ および $30 \mathrm{~g}$ 科取してよく混和し. $1,200^{\circ} \mathrm{C}$ に20時間加熱, 冷却後粉砕し再び $1,200^{\circ} \mathrm{C}$ に 10 時 間加熱した。冷却後粉砕してムスプラット液で処理し未 反応の遊離酸化亜鉛を溶解除去した。沪過洗浄後乾燥し 更に $800^{\circ} \mathrm{C}$ に 1 時間加熱した。分析結果は $\mathrm{SiO}_{2} 34.80 \%$ で $2 \mathrm{ZnO} \cdot \mathrm{SiO}_{2}$ の理論值 $26.90 \%$ りかなり $\mathrm{SiO}_{2}$ が高い。 この試料を $0.5 \mathrm{~N}$ 硫酸で浸出すると不溶解残渣が残りそ
第 3 図

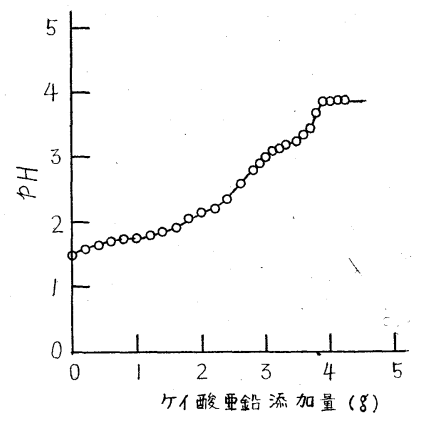

の化学分析結果は $\mathrm{SiO}_{2}$ である。したがつて未反応のケ イ酸が中心部にあり，そのため $\mathrm{SiO}_{2}$ 含有量が理論值よ り高くなつているのである。しかし試料のX線回折では ケイ酸の回折線は認められなかつた。

焼鉱浸出の際ケイ酸要鉛の溶解する硫酸亜鉛溶液の $\mathrm{pH}$ 限界を明らかにするため次のような実験を行なつた。 硫酸亜鉛溶液 $(\mathrm{Zn} 100 \mathrm{~g} / l)$ に硫酸を $0.5 \%$ (容量) 加えた 溶液 $200 \mathrm{~m} l$ に，ケイ酸亜鉛 $0.2 \mathrm{~g}$ を添加し $60^{\circ} \mathrm{C}$ に 2 時間 磁気攪拌しつつ保持後 $\mathrm{pH}$ をガラス電極で測定した。さ らに $0.2 \mathrm{~g}$ のケイ酸亜鉛を添加して同様に行なら。この ような操作をくり返して溶液の $\mathrm{pH}$ 変化を求めた結果は 第 3 図に示すようである。この図からケイ酸亜鉛の溶解 する硫酸亜鉛溶液の $\mathrm{pH}$ 限界值は 3.80 であることが知ら

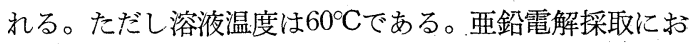
ける酸性溶解の終点㳉 $\mathrm{pH} 2.0 \sim 3.5$ であるから, 焙焼工 程で生成したケイ酸亜鉛は溶解工程の酸性溶解で溶解す るものと思われる。

b ）ケイ酸鉛 実験に使用したケイ酸鉛は次のように して調製した。すなわちケイ石粉末と化学用最純酸化鉛 をモル比 $1: 2$ の割合に科取し十分混和して $700^{\circ} \mathrm{C} に 10$ 時間加熱炉中で泠却した。焼成物は焼結しておりこれを 粉砕して 250mesh 以下にした。X線回折はケイ酸鉛 2 $\mathrm{PbO} \cdot \mathrm{SiO}_{2}$ のみの回折線を示す。

ケイ酸覀鉛の場合と同様, ケイ酸鉛の溶解寸る硫酸要 鉛溶液の $\mathrm{pH}$ 限界を求めた。ケイ酸鉛を $0.2 \mathrm{~g}$ 加えて 2 時間放置しても溶液 $\mathrm{pH}$ は定とならず徐々に上昇した。 したがつて硫酸添加で $\mathrm{pH}$ 調節を行なつた硫酸亜鉛溶液 $(\mathrm{Zn} 100 \mathrm{~g} / l) 100 \mathrm{~m} l$ にケイ酸鉛 $1 \mathrm{~g}$ を加えて磁気䚓拌し ながら $60^{\circ} \mathrm{C} に 24$ 時間および48時間保持し溶液の $\mathrm{pH}$ を測 定した。また残渣はX線回折した。実験結果第 2 表に 示す。

第2表 ケイ酸鉛の分解しなくなる硫酸亚 鉛溶液の $\mathrm{pH}$ 值

\begin{tabular}{c|c|c|c|c}
\hline & 溶液の $\mathrm{pH}$ & $\begin{array}{c}24 \text { 時間後の } \\
\mathrm{pH}\end{array}$ & $\begin{array}{c}48 \text { 時間後の } \\
\mathrm{pH}\end{array}$ & 残 渣 の X 線 分 析 \\
\hline 1 & 0.50 & 0.70 & 0.90 & $\mathrm{PbSO}_{4}$ \\
2 & 1.00 & 2.70 & 3.35 & $\mathrm{PbSO}_{4}+2 \mathrm{PbO} \mathrm{SiO}_{2}$ \\
3 & 1.90 & 3.90 & 5.05 & $\prime \prime$ \\
4 & 2.70 & 5.50 & 5.50 & $\prime \prime$ \\
5 & 4.20 & 5.50 & 5.50 & $\prime \prime$ \\
\hline
\end{tabular}


なお溶液 $\mathrm{pH}$ が高くなるにつれてケイ酸鉛回折線の高 さが高くなるから，溶液 $\mathrm{pH}$ が高くなるほ イ酸鉛は増加している。これらの結果より，ケイ酸鉛は 硫酸と反応して硫酸鉛を生じケイ酸を遊離するが，ケイ 酸鉛の分解が行なわれるのは溶液 $\mathrm{pH}$. 50 までであるこ とが知られる。亜鉛電解採取における中性溶解の終点法 5. 2 5.6であるから, 焙焼工程で生成したケイ酸鉛は中 性溶解の終点まで分解してケイ酸を溶液中に遊離するも のと思われる。しかしケイ酸鉛にあつては反応生成物が 溶解度の小さい硫酸鉛であるためこれが緻密な外層をつ くつて以後の反応を妨害し未反応ケイ酸鉊を中心部に残 す。

以上の実験より, ケイ酸亜鉛は酸性溶解で溶解するこ と，またケイ酸鉛は中性溶解においても分解して溶液中 にケイ酸を遊離することが明らかになつた。

\section{5 電解液中ヶイ酸の状態}

電解液に溶存するケイ酸の状態としては $\mathrm{Si}(\mathrm{OH})_{4 a q}$, これの重合によつて生じた $\left[\mathrm{Si}(\mathrm{OH})_{4}\right]_{n}$ および $\mathrm{Si}(\mathrm{OH})_{4}$ の解離によって生じた $\mathrm{H}_{3} \mathrm{SiO}_{4}$-が考えられる。しかし

$$
\mathrm{H}_{4} \mathrm{SiO}_{4 a q} \rightleftharpoons \mathrm{H}_{3} \mathrm{SiO}_{4}-+\mathrm{H}^{+}
$$

の解離反応の平衡恒数は $p K(-\log K)=9.77 \pm 0.05$ $\left.\left(25^{\circ} \mathrm{C}\right)^{6}\right)$ であるから酸性溶液における $\mathrm{H}_{3} \mathrm{SiO}_{4}$-イオンの 濃度はわずかであろら。

硫酸西鉛一硫酸溶液中に存在するケイ酸が $\mathrm{Si}(\mathrm{OH})_{4 a q}$ であるかあるいはこれが重合してできた $\left[\mathrm{Si}(\mathrm{OH})_{4}\right]_{n}$ な る大分子型のものであるかを明らかにするためモリブデ ン酸による比色法を用いて $\mathrm{Si}(\mathrm{OH})_{4 a q}$ を求めてみた。こ の比色法はケイ酸の定量法として広く使われている方法
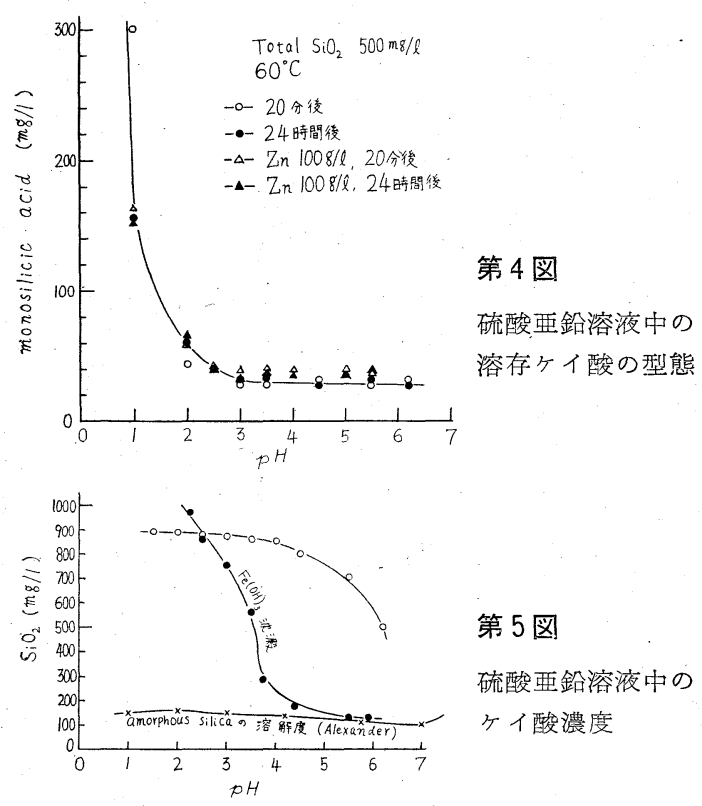

第 5 図

硫酸亜鉛溶液中の ケイ酸濃度
でその原理はモリブデン酸が $\mathrm{Si}(\mathrm{OH})_{4} a q$ および $\mathrm{H}_{3} \mathrm{SiO}_{3}$ と反応して黄色ケイモリブデン酸を生ずるが，重合した $\left[\mathrm{Si}(\mathrm{OH})_{4}\right]_{n}$ とは反応しないということにある7）

実験は次のように行なつた。すなわちケイ酸 $500 \mathrm{mg} / \mathrm{l}$ を含有する硫酸亜鉛溶液 $(\mathrm{Zn} 100 \mathrm{~g} / \mathrm{l})$ とケイ酸含有量は 同一で硫酸亜鉛を含まぬ溶液を，それぞれ硫酸および氷 酸化亜鉛で所定の $\mathrm{pH}$ に調節し $60^{\circ} \mathrm{C} に 20$ 分間および24時 間放置してモリブデン酸アンモン溶液を加え $\mathrm{Si}(\mathrm{OH})_{4} a q$ を比色定量した。その結果は第4 図に示すようで, 溶液 $\mathrm{pH}$ が 2 以上になると $\mathrm{Si}(\mathrm{OH})_{\ell a q}$ 注すみやかに重合し て $\left[\mathrm{Si}(\mathrm{OH})_{4}\right]_{n}$ となることが知られる。

\section{$2 \cdot 6$ 電解液中に溶存するケイ酸の濃度}

水溶液中のケイ酸の溶解度に関しては Alexander等8), Greenberg および Price ${ }^{6}$ ) 等の測定值があるが，亜鉛電 解採取に用いられるような電解液中におけるケイ酸の濃 度については測定值が見当らないので実験を行なつた。

$0.5 \mathrm{~N}$ 硫酸溶液に方イ酸亜鉛を溶解して不溶解残渣(前 述のように未反応のケイ酸）を沪別しこれに硫酸覀鉛を 加えた亜鉛濃度を $100 \mathrm{~g} /$ と とした。の溶液のケイ酸濃度 は $890 \mathrm{mg} / l$ であつた。この溶液 $100 \mathrm{~m} l$ 索とり水酸化亜鉛 で $\mathrm{pH}$ を調節し $60^{\circ} \mathrm{C}$ に96時間保持した。コロイド状沈殿 の生成した場合は乾いたままの沪紙で沪過し，洗浄する ことなく汇液の $50 \mathrm{~m} l$ についてケイ酸を重量法で求め た。結果法第 5 図白丸で示したようで, コロイド状沈殿 として晶出するケイ酸は溶液 $\mathrm{pH} 4.0$ 位までは極めてわ ずかであるが，それ以上の゙ $\mathrm{pH}$ で放置した場合汢コロイ ド状ケイ酸の晶出が急激に増加して溶存ケイ酸注隇少す ることが知られる。

一般に亜鉛電解採取の清浄工程においては $\mathrm{pH} 4.0$ 拉 5.5 亿調節して水酸化第二鉄を主成分とする水酸化物の 沈殿をつくり, 電解液中の不純物を共沈または吸着によ つて除去するといら方法がとられている。水酸化物の溶 解度は溶液の $\mathrm{pH}$ により異なるが, 普通に存在する不純 物の水酸化物溶解度と溶液 $\mathrm{pH}$ との関係を求めると次の ようになる。

金属イオンの加水分解反応

$$
\mathrm{M}^{n+}+n \mathrm{H}_{2} \mathrm{O} \rightleftharpoons \mathrm{M}(\mathrm{OH})_{n}+n \mathrm{H}^{+} \ldots \text { (1) }
$$

の平衡恒数を $k$ とすれば

$$
\log k=\frac{-\Delta G^{\circ}}{2.3 R T}
$$

が成立する。ここに一 $\Delta G^{\circ}$ は生成系と反応系の各成分の 生成遊離エネルギー変化の差で, 各成分についての值が 知られれば容易に求められる。本計算では Rossini 等9 と Latimer ${ }^{10)}$ の值を用いた。

金属イオンの活量を $a_{\mathrm{M}}{ }^{n+}$ とすれば (1) 式について

$$
\log a_{\mathrm{M}}{ }^{n+}=-\log k-n \mathrm{pH}
$$

なる関係が成立するから, 溶液 $\mathrm{pH}$ と溶解度との関係が 


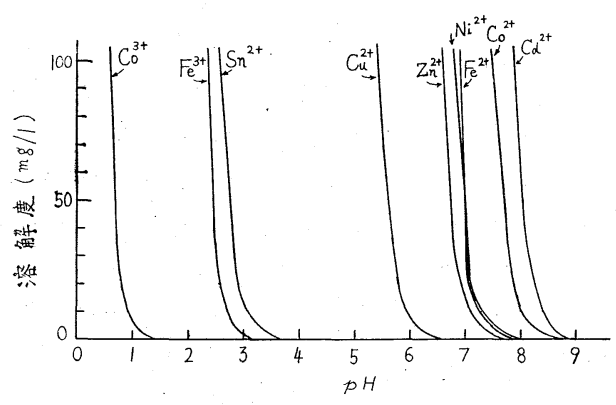

第 6 図 溶液の $\mathrm{pH}$ と水酸化物の溶解度との関係

求められるわけである。計算結果を第 6 図に示す。図よ り清浄工程で $\mathrm{pH}$ を4.0 5.5亿調節すれば $\mathrm{Co}^{3+}, \mathrm{Fe}^{3+}$ および $\mathrm{Sn}^{2+}$ 等は水酸化物となつて沈殿するが他のイオ ンは沈殿しないことが知られる。

清浄工程で水酸化物の沈殿をつくる, 以上のようなイ オンのうち $\mathrm{Fe}^{3+}$ について実験を行なつた。

Zn $100 \mathrm{~g} / l$ (硫酸笽としてて), $\mathrm{SiO}_{2} 980 \mathrm{mg} / l, \mathrm{Fe} 467$ $\mathrm{mg} / l$ ( 硫酸第二鉄として)なる組成の溶液に硫酸を $0.5 \mathrm{~N}$ になるよう添加した後その $100 \mathrm{~m} l$ をつて水酸化亜鉛で $\mathrm{pH}$ を所定の值に調節し $60^{\circ} \mathrm{C}$ に72時間保持した。さきの 場合と同様乾いた沪紙のまま沪過し洗浄は行なわずに沪 液の $50 \mathrm{~m} l$ についてケイ酸を重量法で求めた。その結果 は第 5 図黑丸で示すようで, 明らかに水酸化第二鉄の沈 殿が生成する $\mathrm{pH} 3.5$ 以上では溶存ケイ酸濃度が急激に 減少して無定型ケイ酸の溶解度に近づくことが知られ る。

以上の結果から, 浸出液中のケイ酸は清浄工程で大部 分水酸化第二鉄と共沈し溶存するケイ酸の濃度は無定型 ケイ酸の溶解度に近い $120 \mathrm{mg} / /$ 程度であると見なされ る。

\section{$2 \cdot 7$ 電解液粘度に及ほすすケイ酸の影響}

電解液に溶存するケイ酸の電解液粘度に及ぼす影響に ついて実験を行なつた。硫酸濃度 $0.5 \mathrm{~N}$ で硫酸覀鉊を $\mathrm{Zn}$ として $100 \mathrm{~g} / l$ 含有する場合と含有しない場合につい てケイ酸の影響を求めた。ケイ酸は $1,000 \mathrm{mg} / l$ 加え 測定は $25^{\circ} \mathrm{C}$ でオストワルド粘度計を使用した。測定結果

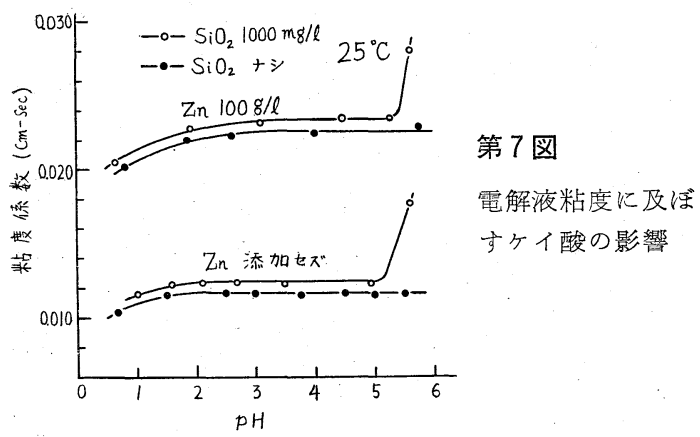

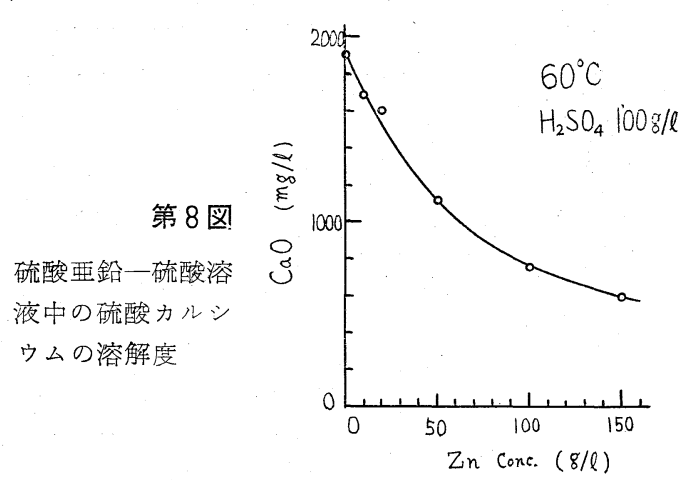

第 9 図

$\mathrm{CaO}-\mathrm{SiO}_{2}-\mathrm{H}_{2} \mathrm{O}$

系比打る溶夜中 の $\mathrm{CaO}$ 濃度と固 体カルシウムケイ 酸塩の $\mathrm{CaO} / \mathrm{SiO}_{2}$ モル比との関係

(H.H.Steinourkよる)

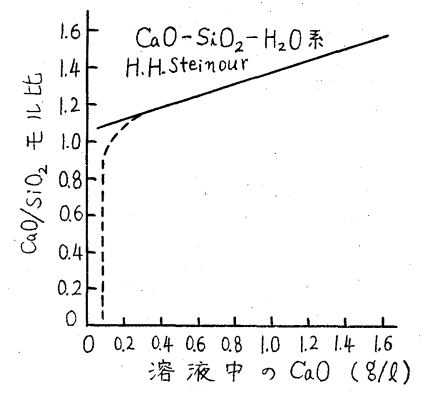

を第 7 図に示す。ケイ酸を含んだ方がわずかであるが粘 度が大きくなる。 $\mathrm{pH} 5.5$ 以上で粘度が急上昇を示すの はコロイド状ケイ酸生成のためである。したがつてコロ イド状ケイ酸が生成されない限り溶存ケイ酸の溶液粘度 に及ぼす影響は僅少であるとみなされる。

\section{$2 \cdot 8$ 不溶性ケイ酸塩の生成}

第 1 表に示したように電解槽底残渣は相当量のケイ酸 を含有する。このケイ酸の組成としては電解液中の金属 イオンとの結合で生じたケイ酸塩が考えられ，そのらち でも最も可能性のあるのはアルカリ土類金属と思われる ので，カルシウムについての実験を行なつた。

まず電解液中のカルシウム飽和濃度が不明なので, 遊 離硫酸濃度を $100 \mathrm{~g} / \mathrm{l}$ 亿一定にし, 亜鉊濃度を変えてカル シウムの飽和濃度を求めた。

亜鉛濃度を異にする硫酸溶液 $200 \mathrm{~m}$ 亿水酸化カルシウ ム $2 \mathrm{~g}$ を添加し磁気攑挥しながら $60^{\circ} \mathrm{C} に 72$ 時間保持後上 澄液 $100 \mathrm{ml}$ をピペットでとつてカルシウムを重量法で求 めた。結果は第 8 図に示す。硫酸溶液中カルシウムの飽 和濃度は硫酸带鉛の増加と共に急激な減少を示す。この 結果より一般に使用されている亜鉛電解採取用電解液組 成にあつては $800 \mathrm{mg} / \mathrm{l}$ 程度の酸化カルシウムが溶解する ものと思われる。

$\mathrm{CaO}-\mathrm{SiO}_{2}-\mathrm{H}_{2} \mathrm{O}$ 系に㧧いて晶出するケイ酸カルシウ ムの組成に関しては多くの研究がある。種々のカルシウ ム濃度の溶液に平衡して存在する固体ケイ酸カルシウム の $\mathrm{CaO} / \mathrm{SiO}_{2}$ モル比は Steinour ${ }^{11)}$ によると第 9 図のよ うであるから, カルシウムを $800 \mathrm{mg} / \mathrm{l}$ 含有する溶液から 
蹋出するケイ酸カルシウムの $\mathrm{CaO} / \mathrm{SiO}_{2}$ モル比は 1.3 に なる。しかし亜鉛電解採取用電解液にあつては多量の遊 離硫酸を含有するので条件が全く異なつている。

実験は次のようにして行なつた。すなわちカルシウム 飽和の硫酸溶液 $\left(\mathrm{H}_{2} \mathrm{SO}_{4}\right.$ 濃度 $\left.100 \mathrm{~g} / l\right) 100 \mathrm{~m} l$.に, ケイ酸 $2,000 \mathrm{mg} / l$ 含有の $0.5 \mathrm{~N}$ 硫酸 $100 \mathrm{~m} l$ を加え, 更に液量が半

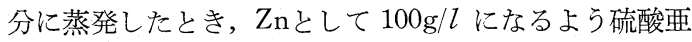
“鉛を加えた。 $60^{\circ} \mathrm{C}$ 亿保持して蒸発せしめ全液量を $100 \mathrm{~m} l$ に至らしめる。晶出した白色沈殿を沪別しエチルアルコ 一ルで洗浄後デシケーター中で乾燥し，X線回折を行な つた。その結果は $\mathrm{CaSO}_{4} \cdot 2 \mathrm{H}_{2} \mathrm{O}$ の回折線が主で，その 他 2,3 不明の回折線が現われた。しかしこの結晶を磁製 ルツボで灼熱し再でX線回折した結果は無水の $\mathrm{CaSO}_{4}$ のみとなつた。すなわち以上のような実験条件ではケイ 酸カルシウムの晶出は全く認められない。

以上流酸カルシウムが晶出するような条件で実験を 行なつたのであるが次にケイ酸を晶出せしめるような条 件で実験を行なつた。すなわち $\mathrm{Zn} 100 \mathrm{~g} / l, \mathrm{H}_{2} \mathrm{SO}_{4} 0.5 \mathrm{~N}$ ， $\mathrm{SiO}_{2} 2,000 \mathrm{mg} / l$ および $\mathrm{CaO} 720 \mathrm{mg} / l$ の溶液 $300 \mathrm{~m} l$ を水酸化亜鉛で $\mathrm{pH} 4.5$ 亿調節し $60^{\circ} \mathrm{C}$ 亿 24 時間保持し た。多量の白色沈殿が生成するので沪過し，洗浄せずに 沪液の $100 \mathrm{~m} l$ についてカルシウムを分析した。その結果 は溶液のカルシウム濃度に変化が認められず, カルシウ ムは全く沈殿していないことを示す。沈殿を直接分析し ないのは適切な洗浄液が不明のためである。

以上の結果加ら亜鉛電解採取の電解液汇あつては, ケ イ酸カルウムは晶出しないと思われる。

\section{3. 結 論}

亜鉛電解採取におけるケイ酸の挙動に関して種々の実 験を行ない，ある程度定量的に明らかにすることができ た。これらをまとめると次のようになる。
（1）亜鉛精鉱中に鉛が存在すれば優先的にケイ酸鉛 が生成する。

（2）ケイ酸亜鉛は酸性溶解では溶解するが，中性溶 解では溶解しない。

（3）ケイ酸鉛は中性溶解でも分解してケイ酸を遊離 する。

（4）ケイ酸は硫酸带鉛一硫酸溶液中で $\mathrm{pH} 2$ 以下で は monosilicic acid であるが, $\mathrm{pH} 2$ 以上になると重 合による polysilicic acid が急に増加する。

（5）浸出液中に溶存し得るケイ酸の濃度は無定型ケ 洒夋の溶解度よりも相当に大であるが，清浄工程におけ るよらに水酸化第二鉄が沈殿すれば共沈によつて無定型 ケイ酸の溶解度にすみやかに近づく。

（6）コロイド状沈殿が晶出しないかぎり電解液粘度 に及ぼすケイ酸の影響は僅少である。

（7）ケイ酸カルシウムの生成は認められない。

$$
\text { 文献 }
$$

1) 日本鉣業協会技術部編：亜鉊カドミウム製錬操業成積(昭和36年 度) 昭和 37 年 10 月

2) A. C. Jephson and R. E. Allen : J. Metals, 9, 1381, 1957.

3) H. Weigel : Erzmetall. 15, 235, 1962.

4) J. A. Kitchener and S. Ignatowicz: Trans. Farad. Soc., 47, $1278,1951$.

5) F. D. Richardson and L. E. Webb: Bull. Inst. Mining Met. No. 584, 529, 1955.

6) S. A. Greenberg and E. W. Price: J. phys. chem., 61, 1539, 1957.

7) F. Dienert and F. Wanderbulcke : Compt. rend. 176, 146, 1923 ; R. W. Harmon: J. Phys. chem., 31, 616, 1927.

8) G. B. Alexander, W. M. Heston and R. K. Iler: J. Phys. Chem., 58, 453, 1954.

9) Rossini F. D., D. D. Wagman, W. H. Evans, Samuel Levine and Irving Jaffe: Selected Values of Chemical Thermodynamic Properties, Natl. Bur. Standards. 1952.

10) Latimer W. M. : Oxidation Potentials. Prentice-Hall Englewood Cliffs. N. J. 1952.

11) H.H. Steinour: Chem. Revs. 40, 391, 1947.

\section{新著紹介}

\section{金属および合金の熱力学的データ集}

R. Hultgren, R. L. Qrr, P. D. Anderson, K.K. Kelley : Selected Values of Thermodynamic Properties of Metals and Alloys

カリフォルニア大学の金属学教窒 ル拈いてとりまとめられたもので, 各種金属の备温度に打忷る比熱, エ ンタルピー,エントロピー, 自由エネ ルギー, 蒸気圧などの熱力学的デー タおよび広範にわたる二元合金につ
いてその状態図に対応させながら， 各相の生成熱，自由エネルギ一，比 熱，エンタルピーなどの熱力学的デ 一タを各種文献より集成している。

$\mathrm{Zn}-\mathrm{Al}, \mathrm{Zn}-\mathrm{Cu}, \mathrm{Pb}-\mathrm{Zn}, \mathrm{Al}-\mathrm{Cu}$ な ぞいろいろの二元合金に関する熱力
学的性質を正確に理解するのにきう めて有益な資料である。(三野英彦)

発行所 : John Wiley \& Sons, Inc, 1963

$¥ 5,000$ (丸善) 